relationship is a major factor in the reluctance of many doctors to seek fully informed consent from patients entering clinical trials ${ }^{9}$ or actually to participate in such trials. ${ }^{17}$ Our study did not show any difference for the two consent procedures in the doctor-patient relationship (as perceived by the patient), although because of the low power of the study an adverse effect cannot be ruled out.

In conclusion, our results clearly indicate some trade offs when patients are given all the relevant information compared with an individual approach to obtaining consent. Patients in the total disclosure group had a greater understanding of their treatment and of the research aspects of the trial but at the expense of increased anxiety. We hope that these results will stimulate similar controlled trials of consent practices at other hospitals, where the individual style of seeking consent may differ.

We are indebted to Stan Kaye and Margaret Brodie for their help in planning the study; to Cheryl Sutherland and Cheryl Swanson, who undertook the questionnaire interviews; to Richard Fox, David Hedley, Fred Kirsten, Graham Mann, and Ann Sullivan for their help with the consent interviews; and to Judy Hood for secretarial help. Dr Simes received support from an NH and MRC (Australia) Applied Health Sciences Fellowship. Statistical analysis, done at Dana Farber Cancer Institute, Boston, Massachusetts, USA, was supported by NCI grant number CA-23415.

\section{References}

1 Anonymous. Consent: how informed? [Editorial.] Lancet 1984;i: 1445-7.

2 Cancer Research Campaign Workıng Party in Breast Conservation. Informed consent: ethical, legal and medical implications for doctors and patients who participate in randomised clinical trials. Br Med f 1983;286:1117-21.

3 Anonymous. Research, consent, distress and truth. [Editorial.] f Med Ethics 1982;8:59-60.

4 Giertz G. Ethics of randomized clinical trials. I Med Ethics 1980;6:55-7.

5 Anonymous. Secret randomized trials. [Editorial.] Lancet 1982;ii:78-9.

6 Brewin TB. Consent to randomized treatment. Lancet 1982;ii:919-21.

7 Shafer A. The ethics of the randomized clinical trial. N Engl f Med 1982;307:719-24.

US Government Food and Drug Administration Code of Federal Regulations. Washington DC: US Government Printing Office, 1982 (DHEW publication): 191-3.

9 Ingelfinger FJ. Informed (but uneducated) consent. N Engl f Med 1972;287:465-6.

10 Taylor KM, Margolese RG, Soskolne CL. Physicians reasons for not entering patients in a randomized clinical trial of surgery for breast cancer. N Engl f Med 1984;310:1363-7.

11 Hellman S. Editorial: Randomized clinical trials and the doctor-patient relationship. Cancer Clinical Trials 1979:2:189-93.

12 Brewin TB. Truth, trust and paternalism. Lancet 1985;ii:490-2.

13 Kassirer JP. Adding insult to iniury. Usurping patients' prerogatives. $N$ Engl $\mathcal{f}$ Med 1983:308:898-901.

14 Kirby MD Informed consent: what does it mean? f Med Ethics 1983;9:69-75.

14 Kirby MD. Informed consent: what does it mean? J Med Eth

15 Annas

16 Anonymous. On telling dying patients the truth. [Editorial.] f Med Ethics 1982;8:115-6.

17 Zelen $M$. The randomisation and stratification of patients to clinical trials. $\mathcal{J}$ Chronic Dis 1974;27:365-75

18 Spielberger CD, Gorsuch RL, Lushene RE. STAI annual for the state-trait anxiety inventory. Palo Alto: Consulting Psychologists Press, 1970.

19 Morrison DF. Multivariate statistical methods. New York: McGraw Hill, 1967;120, 223.

20 Mehta CR, Patel NR. A network algorithm for Fisher's exact test in rxc contingency tables. Journal of the American Statistical Association 1983;78:427-34.

21 Cassileth BR, Zupkis RV, Sutton-Smith K, March V. Informed consent-why are its goals imperfectly realized? $N$ Engl f Med 1980;302:896-900.

22 Epstein LC, Lasagna L. Obtaining informed consent. Form or substance? Arch Int Med 1969;123:682-8.

23 Morrow G, Gootnick J Schmale A A simple technique for increasing cancer patient's knowledge of informed consent to treatment. Cancer 1978;42:793-9.

24 Zelen M. A cew design for andomized clinical trials. N Englf Med 1979-300:1242-5.

25 Ellenberg SS. Randomization designs in comparative clinical trials. N Engl f Med 1984;310: 1404-8.

26 Gehan EA, Freireich EJ. Cancer clinical trials. A rational basis for use of historical controls. Semin Oncol 1981;8:430-6.

(Accepted 14 fuly 1986)

\title{
Decline in cardiovascular mortality in North Karelia and other parts of Finland
}

\author{
JAAKKO TUOMILEHTO, JEF GEBOERS, JUKKA T SALONEN, AULIKKI NISSINEN, \\ KARI KUULASMAA, PEKKA PUSKA
}

\begin{abstract}
The trends in mortality from ischaemic heart disease, cerebrovascular stroke, and all cardiovascular diseases were analysed for the province of North Karelia and for the rest of Finland. Linear trends in mortality were computed for the population aged 35 to 64 for the period from 1969 to 1982 , and changes in mortality between the three year means of 1969-71 and 1980-2 were calculated. In North Karelia, where a community based preventive programme has been carried out since 1972, the annual decline in mortality from ischaemic heart disease in men was on average $\mathbf{2 . 9 \%}$, whereas in the rest of Finland it was $2 \cdot 0 \%$. For
\end{abstract}

Department of Epidemiology, National Public Health Institute, 00280 Helsinki, Finland

JAAKKO TUOMILEHTO, MD, MPOLSC, professor

AULIKKI NISSINEN, MD, NT, assistant professor

KARI KUULASMAA, PHD, biostatistician

PEKKA PUSKA, MD, MPOLSC, professor

Department of Epidemiology, University of Leuven, Leuven, Belgium JEF GEBOERS, LICSC, biostatistician

Department of Community Health, University of Kuopio, Kuopio, Finland JUKKA T SALONEN, MD, MPH, professor

Correspondence to: Dr Tuomilehto. women the respective average annual declines in mortality were $4.9 \%$ and $3.0 \%$. The net decline from $1969-71$ to $1980-2$ in North Karelia was 100 deaths $/ 100000$ men. The annual mortality from all cardiovascular disease in men decreased by $2.9 \%$ in North Karelia and by $2.6 \%$ in the rest of Finland; in women the decreases were $6.0 \%$ and $5.0 \%$ a year, respectively. The net decline in North Karelia was 71 deaths/100000 men. The decline in mortality from all causes was also appreciable in both sexes in North Karelia, but it did not differ significantly from national trends.

\section{Introduction}

Awareness of the high incidence of cardiovascular disease in $\bar{O}$ Finland as a whole, and in North Karelia in particular, ${ }^{1.4}$ resulted in 0 a comprehensive, community based preventive programme to control cardiovascular disease: the North Karelia project. ${ }^{5}$ Its aim was to reduce mortality and morbidity from cardiovascular disease by reducing established risk factors, such as smoking, high serum cholesterol concentrations, and blood pressure, in the entire community. The favourable effects of this effort on these risk factors have been reported previously. ${ }^{5.8}$

Previous analyses have suggested that in the mid-1970s mortality from ischaemic heart disease started to decline faster in North Karelia than in the rest of Finland. ${ }^{9}$ In this report we estimate the trends in mortality from cardiovascular disease in North Karelia 
from 1969, three years before the start of the project, to 1982, the last year for which data were available at the time of the analysis. This period therefore covers the first 10 years of the project. Comparison between the trends in North Karelia and the rest of Finland reflects the effects of the project, though such trends are inter-related in a complex way.

\section{Methods}

The data on deaths for the years from 1969 to 1982 were obtained from the Central Statistical Office of Finland. In that office the diagnoses made by local doctors on the individual death certificates are reviewed by a nosologist according to the guidelines of the International Classification of Diseases, Injuries, and Causes of Death (ICD). The eighth revision of the ICD was adopted in Finland in 1969 and covers the entire period of study. Data for the following categories were analysed separately for men and women: all causes; ischaemic heart disease (ICD code A83 (410-414)); cerebrovascular stroke (ICD code A85 (430-438)); and all cardiovascular diseases (ICD code A81-A86 (397-459)). The mid-year population totals were used as denominators to calculate annual mortalities. The population data for 1970 and 1980 were based on census information; those for other years were based on registration of births, deaths, and migration.

Mortalities were calculated for each province of Finland for each year from 1969 to 1982 . They were standardised for age with 10 year age groups, with the population distribution of men and women in the whole country in 1972 as the standard. Linear regression slopes (b) were calculated for North Karelia and the rest of Finland (excluding the island province Åland because the numbers were too small) for the entire 14 year period. ${ }^{10}{ }^{11}$ These slopes were then used to calculate relative percentage annual changes in mortality according to the formula: Relative change $=100 \mathrm{~b} / \mathrm{M}(\mathrm{x})$, where $\mathrm{M}(\mathrm{x})$ is the average mortality from a cause $x$ from 1969 to 1982 . The significance of the difference in relative changes in mortality between North Karelia and the rest of Finland during the study was evaluated with a test to compare two linear transformations of regression slopes. ${ }^{10}$

Changes in mortality during the first 10 years of the project were also calculated as the difference between the average mortality during the period from 1969 to 1971 - that is, before the start of the project-and the most recent three years during the 10 year follow up-that is, 1980 to 1982 . Net decline in mortality in North Karelia was calcuated as the difference between these changes (absolute net decline).

As mortality from causes examined is higher in North Karelia than in the rest of the country comparisons based on relative changes (relative annual change) make differences in the province of North Karelia look smaller than in comparisons based on absolute changes (net decline and regression slope).

\section{Results}

Figure 1 shows the age standardised annual mortality from cardiovascular disease for men and women aged 35 to 64 in the 11 provinces of Finland, with the fitted regression slopes for North Karelia and the other 10 counties. In both men and women the mortality from cardiovascular disease estimated by the slope of linear regression decreased between 1969 and 1982 (table I).

Figure 2 shows the age specific regression slopes for mortality from cardiovascular disease in the 10 year age groups 35-44, 45-54, and 55-64, while table II shows the regression based percentage changes. An appreciable decline in mortality from cardiovascular disease was observed in all age
TABLE II-Annual regression based percentage decrease in mortality from all cardiovascular diseases in men and women aged 35 to 44

\begin{tabular}{cccccc}
\hline & \multicolumn{2}{c}{ North Karelia } & & \multicolumn{2}{c}{ Rest of Finland } \\
\cline { 2 - 3 } \cline { 5 - 6 } Age group (years) & Men & Women & & Men & Women \\
\hline $35-44$ & $6 \cdot 1$ & $7 \cdot 1$ & & $5 \cdot 2$ & $5 \cdot 8$ \\
$45-54$ & $2 \cdot 7$ & 6.1 & & $2 \cdot 8$ & $5 \cdot 7$ \\
$55-64$ & $2 \cdot 5$ & 5.9 & & $2 \cdot 2$ & $4 \cdot 8$ \\
\hline
\end{tabular}

groups. In men the percentage change was greatest in the youngest age group, but the regression slope was steepest in the oldest age group. The regression slope for mortality from cardiovascular disease was somewhat steeper for North Karelian women than for those in the rest of Finland. At the start of the study the annual mortality from cardiovascular disease in North Karelian men and women was higher than that for the rest of Finland in each age group. At the end of the study, however, mortality in the two

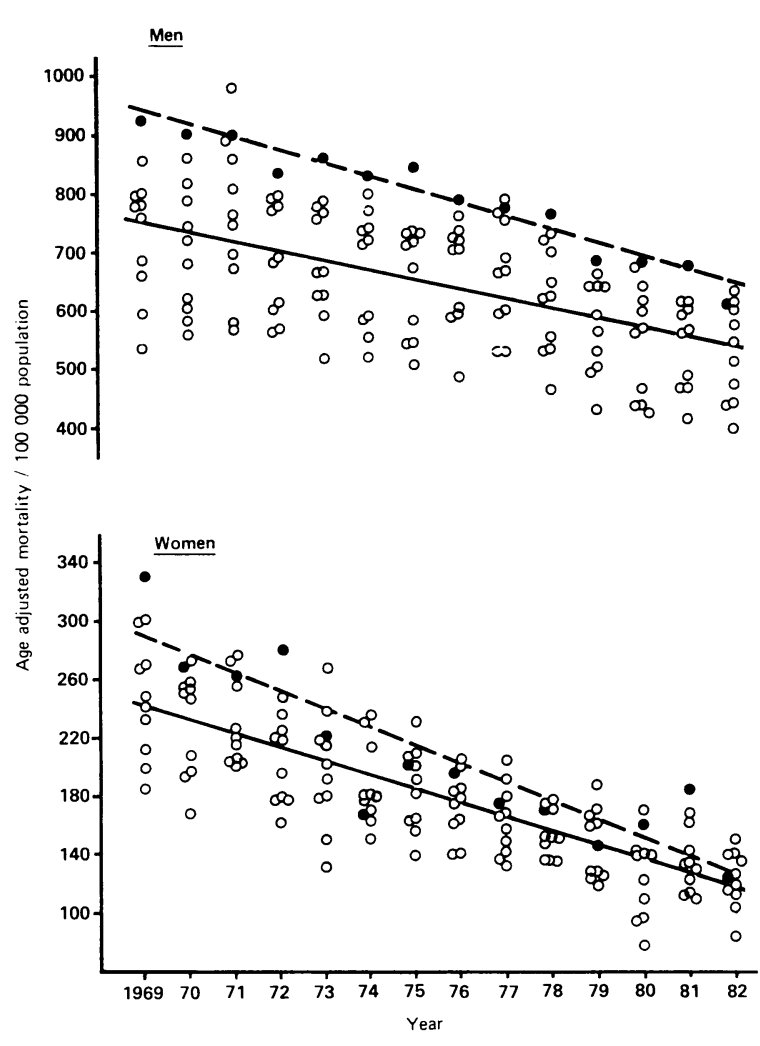

FIG 1-Age standardised annual mortality from all cardiovascular diseases/100 000 population in men and women aged 35 to 64 from 1969 to 1982 in North Karelia $(0)$ and 10 other Finnish provinces $(\bigcirc)$ with fitted regression lines $(---=$ North Karelia, $-=$ rest of country).

TABLE I-Trends in mortality from selected causes for men and women aged 35 to 64 in North Karelia and rest of Finland 1969 to 1982

\begin{tabular}{|c|c|c|c|c|c|c|c|c|c|c|}
\hline & \multicolumn{4}{|c|}{ Mean mortality } & \multirow{3}{*}{$\begin{array}{c}\text { Net decline in } \\
\text { mortality in } \\
\text { N Karelia } \\
100000 \\
\text { population }\end{array}$} & \multirow{2}{*}{\multicolumn{2}{|c|}{$\begin{array}{l}\text { Regression slope } \\
\text { of linear trend }\end{array}$}} & \multirow{2}{*}{\multicolumn{3}{|c|}{ Relative annual change $(\%) \dagger$}} \\
\hline & \multicolumn{2}{|c|}{1969 to 1971} & \multicolumn{2}{|c|}{1980 to 1982} & & & & & & \\
\hline & N Karelia & Rest of Finland & N Karelia & Rest of Finland & & N Karelia & Rest of Finland & N Karelia & Rest of Finland & Significance \\
\hline \multicolumn{11}{|c|}{ Men } \\
\hline All causes & 1598 & 1349 & 1177 & 1006 & 78 & $-34 \cdot 8$ & $-30 \cdot 0$ & $2 \cdot 5$ & $2 \cdot 5$ & NS \\
\hline All cardiovascular diseases & 911 & 689 & 655 & 504 & 71 & $-22 \cdot 8$ & $-15 \cdot 7$ & $2 \cdot 9$ & $2 \cdot 6$ & NS \\
\hline Ischaemic heart disease & 715 & 493 & 508 & 386 & 100 & $-17 \cdot 7$ & $-8 \cdot 8$ & $2 \cdot 9$ & 1.9 & $p<0.05$ \\
\hline Cerebrovascular disease & 95 & 101 & 65 & 60 & -11 & $-3 \cdot 0$ & $-3 \cdot 6$ & $3 \cdot 0$ & $4 \cdot 4$ & NS \\
\hline \multicolumn{11}{|c|}{ Women } \\
\hline All causes & 542 & 508 & 366 & 356 & 24 & $-15 \cdot 5$ & $-13 \cdot 5$ & $3 \cdot 4$ & $3 \cdot 2$ & NS \\
\hline All cardiovascular diseases & 288 & 221 & 158 & 124 & 33 & $-12 \cdot 5$ & $-8 \cdot 6$ & $6 \cdot 0$ & $5 \cdot 0$ & NS \\
\hline Ischaemic heart disease & 131 & 90 & 77 & 63 & 27 & $-4 \cdot 7$ & $-2 \cdot 4$ & 4.9 & $3 \cdot 0$ & $p<0.05$ \\
\hline Cerebrovascular disease & 70 & 75 & 47 & 38 & -14 & $-3 \cdot 1$ & $-3 \cdot 2$ & $5 \cdot 6$ & $6 \cdot 0$ & NS \\
\hline
\end{tabular}

*Defined as change in mortality in North Karelia-change in mortality in rest of Finland.

$\dagger$ Defined as $100 \mathrm{xb} / M$, where $b$ is the linear regression slope and $M$ is the average mortality over the period. 

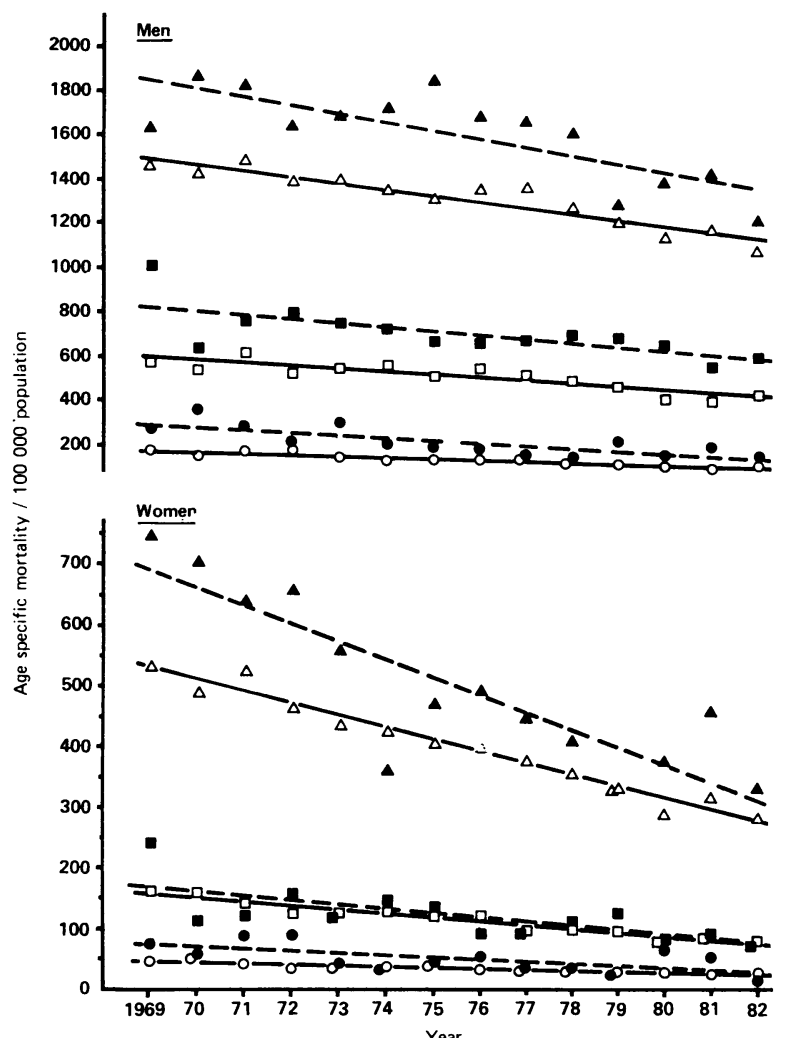

FIG 2-Age specific annual mortality from all cardiovascular diseases/ 100000 population for men and women in 10 year age groups. Ages 55-64: $\boldsymbol{\Delta}=$ North Karelia, $\Delta=$ rest of Finland. Ages 45-54: $\square=$ North Karelia, $\square=$ rest of Finland. Ages 35-44: $0=$ North Karelia, $\mathrm{O}=$ rest of Finland. Fitted regression lines:.$--=$ North Karelia, $=$ rest of Finland.

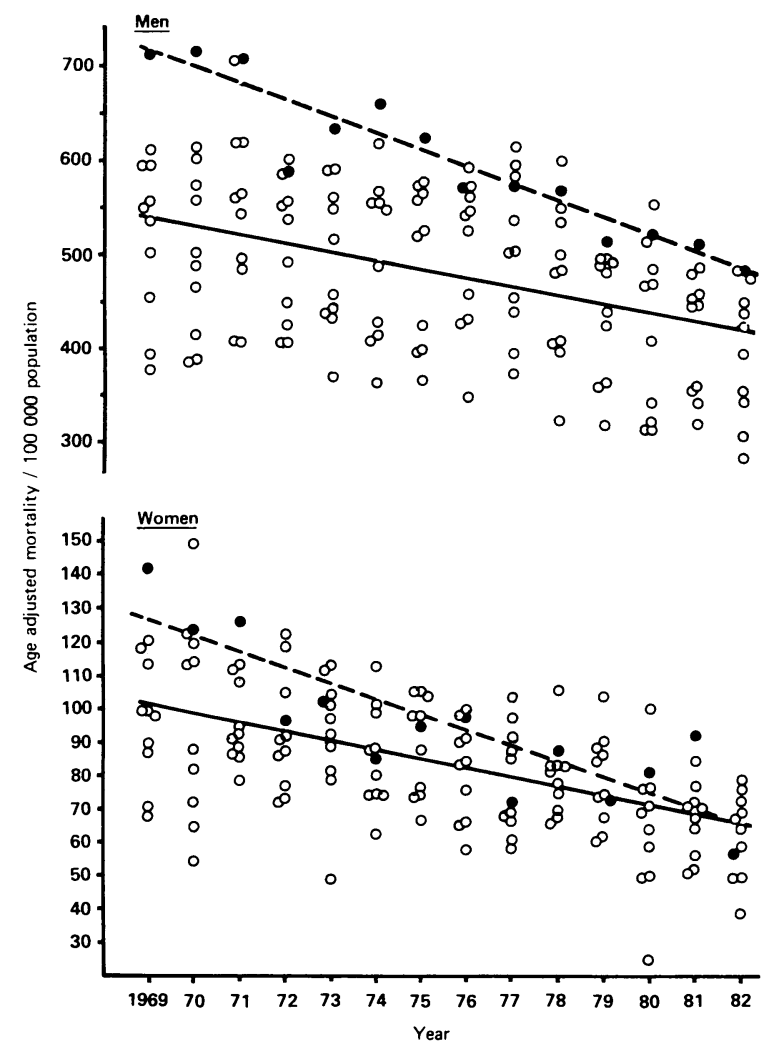

FIG 3-Age standardised annual mortality from ischaemic heart disease/ 100000 population in men and women aged 35 to 64 from 1969 to 1982 in North Karelia $(O)$ and 10 other Finnish provinces $(O)$ with fitted regression lines $(-\ldots=$ North Karelia, $-=$ rest of country). younger age groups of North Karelian women had reached the national average (fig 2).

Figure 3 shows the age standardised annual mortality from ischaemic heart disease for men and women in North Karelia and the rest of Finland, and table I shows the average annual decrease in mortality from ischaemic heart disease. Figure 4 shows the age standardised annual mortality from cerebrovascular stroke for men and women in North Karelia and the rest of Finland, while table I shows the average annual decline in mortality from cerebrovascular stroke. Mortality from stroke in men in North Karelia varied considerably during the first part of the study. Only after 1976 did a steady and steep decline occur (fig 4).

Total mortality in North Karelia declined significantly among men and women. Among men this relative decline was no greater than that in the rest of Finland (table I)

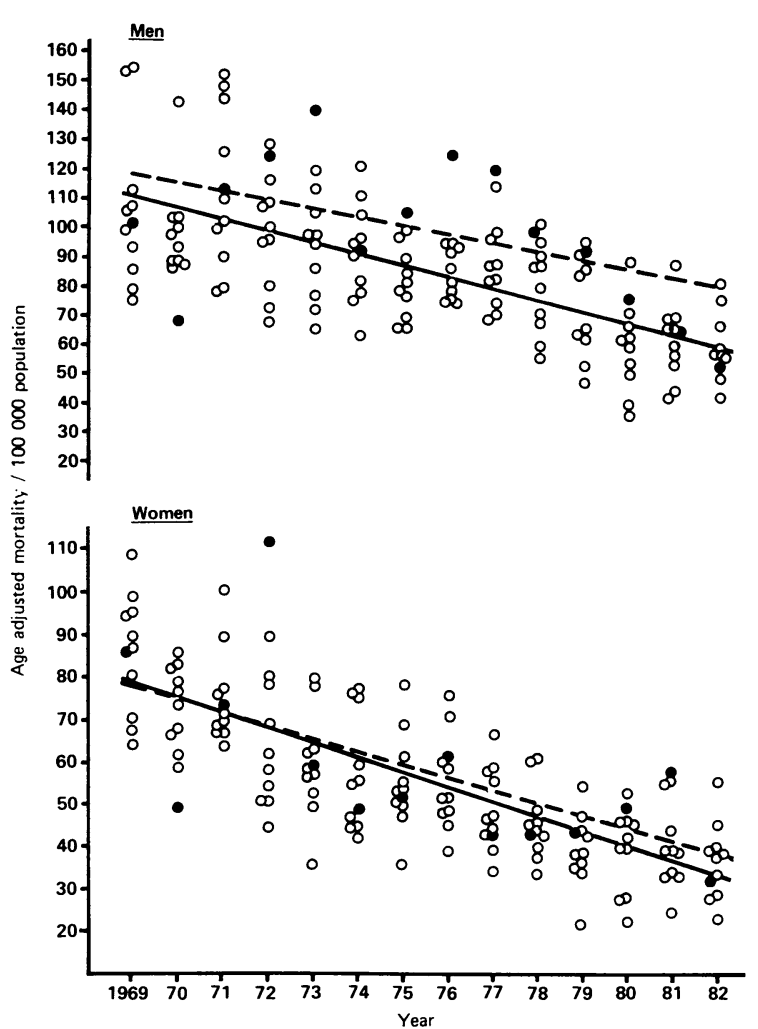

FIG 4-Age standardised annual mortality from cerebrovascular stroke/ 100000 population in men and women aged 35 to 64 from 1969 to 1982 in North Karelia $(O)$ and 10 other Finnish provinces $(\bigcirc)$ with fitted regression lines $\left(-\cdots=\right.$ North Karelia, $\_=$rest of country).

\section{Discussion}

In our earlier reports we have shown that mortality from ischaemic heart disease in North Karelian men started to decrease particularly steeply from 1974 onwards-that is, two years after the start of the North Karelia project. Preventive activities similar to the North Karelia project have gradually been launched nation wide, partly based on the experience gained from the project.

The linear trend for the entire period from 1969 to 1982 in our present analyses is a conservative evaluation of the trend in mortality in relation to the intervention programme, as the programme started only in 1972. The possible effect on the trend of the intervention programme is not taken into account in this analysis, which is based on linear trends. As can be seen in the analysis of stroke mortality among men, an analysis that takes into account the possible time lag between effects on risk factors and mortality would change the results in favour of North Karelia.

For Finland as a whole we found an average annual decline in mortality from ischaemic heart disease of about $2.0 \%$ in men and $3.0 \%$ in women. Mortality from stroke decreased annually by $4.4 \%$ in men and $6.0 \%$ in women, and mortality from cardiovascular disease decreased by $2 \cdot 6 \%$ in men and $5 \cdot 0 \%$ in women (table I). In 
men these national decreases mostly took place during the last few years, later than in North Karelia. The decline in mortality from cardiovascular disease in Finland is now one of the steepest in the world. Annual declines of the same magnitude have been found only in Australia and the United States. ${ }^{12-16}$

The decrease in mortality from ischaemic heart disease in North Karelian men was significantly greater than that in the rest of the country. The present results support the earlier finding that the decline in mortality from ischaemic heart disease in North Karelian men was especially great after $1974 .^{9}$ In fact mortality from ischaemic heart disease in men in North Karelia decreased on average by $4 \cdot 3 \%$ a year from 1974 to 1982 .

Mortality from stroke in Finland, which used to be among the highest in Europe in the 1950s, has declined steeply. ${ }^{17}$ During the 1970 s the decline was particularly rapid, ranking with the decline in Japan as the fastest in the world. ${ }^{17.19}$ Owing to relatively few deaths from stroke in the age category 35 to 64 and the unreliability of the diagnostic classification in earlier years the annual mortality for individual provinces varied considerably. It was surprising that the mean mortality from stroke in Finland as a whole did not change much from 1979 to 1982 . This stability may show that treatment for hypertension did not improve during those years in terms of either the number of treated patients or the effectiveness of antihypertensive drug treatment. ${ }^{20-22}$ In North Karelian men mortality from stroke started to decline only in 1976, but the decrease since then has been very rapid-about $14 \%$ a year. The main improvements in hypertension control in North Karelian men took place from 1974 to $1977 .{ }^{21}{ }^{22} \mathrm{We}$ cannot explain why the decrease and difference in the decline in favour of North Karelia among men started earlier for ischaemic heart disease than for cerebrovascular stroke.

In 1982 mortality from ischaemic heart disease in North Karelian women was for the first time below the national average. Mortality from all cardiovascular diseases in North Karelian women declined very steeply from 1972 , by about $6.0 \%$ a year, and approached the national average in 1982. The downward trend in mortality from ischaemic heart disease and cardiovascular disease seemed to take place during the entire period of the study, though we must be cautious about interpreting trends over shorter periods, especially in small numbers of women. An increasing trend in mortality from stroke was seen in North Karelian women from 1977 to 1981. This has been associated with some relapses in drug treatment of hypertensive women during this period. ${ }^{21}$

Finally, we may ask whether the greater decline in mortality from ischaemic heart disease and cardiovascular disease in North Karelia, as well as the lesser decline in the rest of the country, really was due to changes in risk factors. Our analysis was not based on a trial, but the decline in both North Karelia and the whole country seems to agree with the information available on changes in risk factors. The greater decline in mortality from ischaemic heart disease in North Karelia is also in accord with the greater change in risk factors in that province than in the rest of Finland ${ }^{523-25}$ (A Nissinen et al, unpublished). This difference in the change in risk factors is attributed to the comprehensive intervention carried out in North Karelia since 1972, though the matter is further complicated because intervention in North Karelia has also influenced development in the whole country, especially since 1977 after the first five years of the project. As we cannot think of any reason for the greater decline of mortality from ischaemic heart disease in North Karelia other than the prevention programme it is reasonable to argue that it was a consequence of the project. Although mortality in 1969 to 1971 in North Karelia was the highest among the Finnish provinces, a review of the changing trends in all provinces indicates that the regression to the mean explains neither the greater decline in North Karelia nor differences in the decline between different areas of Finland. ${ }^{9}$

To conclude, this analysis of cardiovascular mortality in North Karelia shows a favourable trend over the past 14 years. Furthermore, cardiovascular mortality seems to have decreased more in North Karelia than in the rest of Finland. The North Karelia project has probably had a great influence on this recent favourable development in Finland, especially in the study area of North Karelia.

\section{References}

1 Keys A. Coronary heart disease in seven countries. Dallas: American Heart Association, 1970. (Monograph No 29.)

2 Ovcarov VK, Bystrova VA. Present trends in mortality in the age group 35-64 in selected developed countries between 1950-1973. World Health Stat $Q$ 1978;31:208-346.

3 Leppo K, Lindgren J, Ritamies M. Mortality trends in Finland in the 1960s. In: Yearbook of population research in Finland. XII. 1971. Helsinki: Population Research Institute, 1972.

population reseurch in Finland. XII. 197I. Helsinki: Population Research Institute, 1972.
4 Puska P. Sydän- ja verisuonitautikuolleisuuden alueelliset erot Suomessa (Regional differences in CVD mortality in Finland). Suomen Lääkärilehti 1972;27:3071-5.

5 Puska P, Tuomilehto J, Salonen JT, et al. Community control of cardiovascular diseases-the North Karelia project: evaluation of a comprehensive community programme for control of cardiovascular diseases in 1972-77 in North Karelia. Copenhagen: World Health Organisation/EURO, 1981.

6 Salonen JT, Puska P, Kottke TE, Tuomilehto J. Changes in smoking, serum cholesterol and blood pressure levels during a community-based cardiovascular disease prevention programthe North Karelia project. Am J Epidemiol 1981;114:81-94.

7 Puska P, Salonen JT, Nissinen A, et al. Change in risk factors for coronary heart disease during 10 years of a community intervention programme (North Karelia project). Br Med $\mathcal{~}$ 1983;287: 1840-4.

8 Puska $\mathrm{P}$, Nissinen A, Tuomilehto J, et al. The community-based strategy to prevent coronary heart disease: conclusions from the ten years of North Karelia project. Annu Rev Public Health 1985;6:147-93.

9 Salonen JT, Tuomilehto J, Puska P, Nissinen A, Kottke TE. Decline in mortality from coronary heart disease in Finland from 1969 to 1979. Br Med J 1983;286:1857-60.

10 Draper N, Smith H. Applied regression analysis. 2nd ed. New York: John Wiley and Sons, 1981.

1 Armitage P. Statistical methods in medical research. Oxford: Blackwell Scientific Publications, 1971:281-4.

12 Havlik RJ, Feinleib M, eds. Proceedings of the conference on the decline in coronary heart disease mortality. Bethesda, Maryland: Public Health Service, National Institutes of Health, 1979. (NIH publication No 79-1610.

13 Dwyer T, Hetzel BS. A comparison of trends of coronary heart disease mortality in Australia, USA, and England and Wales with reference to three major risk factors-hypertension, cigarette smoking and diet. Int $\mathcal{E}$ Epidemiol 1980;9:65-71.

14 Dobson AJ, Gibberd RW, Wheeler DJ, Leeder SR. Age specific trends in mortality from ischemic heart disease in Australia. Am J Epidemiol 1981;113:407-12.

15 Stamler J. The marked decline in coronary heart disease mortality rates in the United States, 1968-1981: summary of findings and possible explanations. Cardiology 1985;72:11-22.

16 Hardes GR, Dobson AJ, Lloyd DM, Leeder SR. Coronary heart disease mortality trends and related factors in Australia. Cardiologv 1985;72:23-8.

17 Tuomilehto J, Geboers J, Joossens JV, Salonen JT, Tanskanen A. Trends in stomach cancer and stroke in Finland. Comparison to northwest Europe and USA. Stroke 1984;15:823-8.

18 Joossens JV. Stroke, stomach cancer and salt. A clue to the prevention of hypertension. In Kesteloot H, Joossens JV, eds. Epidemiology of anerial blood pressure. The Hague: Martinus
. Kesteloot $\mathrm{H}$, Joossens JV, eds. Epidemiolog
Niihoff Medical Division, 1980:489-508.

19 Joossens JV, Geboers J. Nutrition and gastric cancer. Nutr Cancer 1981;2:250-61.

20 Tuomilehto J, Nissinen A, Wolf E, Geboers J, Piha T, Puska P. Effectiveness of antihypertensive drug treatment and trends in stroke mortality in the community. Br Med f 1985;291:857-61.

21 Tuomilehto J, Nissinen A, Wolf E, Geboers J, Puska P. Hypertension control in the communitythe ten-year experience in North Karelia, Finland. In: Yamori Y, Lenfant C, eds. Prevention of cardiovascular disease - an approach to active long life. Amsterdam: Elsevier Science Publishers (in press).

22 Tuomilehto J, Nissinen A, Salonen J, Kottke TE, Puska P. Community programme for control of hypertension in North Karelia, Finland. Lancet 1980;ii:900-4

23 Karvonen M, Blomqvist G, Kallio V, et al. Epidemiological studies related to coronary heart disease: characteristics of men aged 40-59 in seven countries. C4. Men in rural east and west Finland. Acta Med Scand [suppl] 1967;460:169.

24 Puska $P$, Rimpelä $M$. Epidemiology of coronary heart disease and its risk indicators in south-west and east Finland. Nordic Council for Arctic Medical Research Report 1974;7:21-6.

25 Puska P, Koskela K. Community-based strategies to fight smoking. Experiences from the North Karelia project in Finland. NY State $\mathcal{Y}$ Med 1983;83:1335-8.

(Accepted 7 August 1986 